\title{
KARAKTERISTIK SIFAT MEKANIS DAN STRUKTUR MIKRO PROSES AUSTEMPER PADA BAJA KARBON S 45 C DAN S 60 C
}

\author{
Lim Richie Stifler, Sobron Y.L. dan Erwin Siahaan \\ Jurusan Teknik Mesin, Fakultas Teknik Universitas Tarumanagara
}

\begin{abstract}
Steel is an iron-carbon alloys containing concentrations of other alloys having a different composition and treatment materials, steel properties can be changed by heat treatment. The heat treatment process serves to increase the strength of a steel material. The nature of the material can be turned into a more robust and resilient heat treatment process, if done properly and correctly. Austempering process is just one example of the heat treatment process at steel that aims to improve the mechanical properties of the steel S $45 C$ and S 60 C. austempering process performed on the steel S 45 $C$ and $S 60$ C aims to increase the hardness and toughness of the steel. Austempering process is done by austenisasi advance with temperature $850^{\circ} \mathrm{C}$ and held for 60 minutes, after which the process is carried out with 3 election austempering temperature of $350^{\circ} \mathrm{C}, 450^{\circ} \mathrm{C}, 550^{\circ} \mathrm{C}$ and held for 30 minutes. The method used to test the results of austempering is tensile testing using ASTM A370-12a, Vickers hardness test and microstructure observation using a digital microscope. In the test results tensile steel S $45 \mathrm{C}$ and $S 60$ C values obtained an increase in ductility and toughness of $17.1 \%$ on steel S 45 C and $17 \%$ on steel $S 60 \mathrm{C}$. This value is obtained from the calculation of ultimate tensile strength test specimens that have not been in austempering process with a specimen that has been in the process of austempering at $350^{\circ} \mathrm{C}$, and the results of testing hardness of the steel S $45 C$ and S 60 C obtained hardness value of $44 \%$ increase in steel S 45 C and $46 \%$ on steel S 60 C. value this is obtained from the calculation of the average value of the test specimen is not in the process of austempering with a specimen that has been in the process of austempering at $350^{\circ} \mathrm{C}$.
\end{abstract}

Keywords: heat treatment , carbon steel , austemper , austempering , austempering carbon steel.

\begin{abstract}
Abstrak: Baja adalah besi karbon campuran logam yang berisi konsentrasi dari campuran logam lainnya yang mempunyai perlakuan bahan dan komposisi berbeda, Sifat baja dapat diubah dengan perlakuan panas. Proses perlakuan panas berfungsi untuk meningkatkan kekuatan suatu material baja. Sifat dari material tersebut dapat berubah menjadi lebih kuat dan ulet apabila dilakukan proses perlakuan panas dengan tepat dan benar. Proses austempering adalah salah satu contoh proses perlakuan panas pada baja yang bertujuan untuk meningkatkan sifat mekanis pada baja S 45 C dan S 60 C. Proses austempering dilakukan pada baja S 45 C dan S 60 C bertujuan untuk meningkatkan kekerasan dan ketangguhan dari baja tersebut. Proses austempering dilakukan dengan melakukan austenisasi terlebih dahulu dengan suhu $850^{\circ} \mathrm{C}$ dan ditahan selama 60 menit, setelah itu dilakukan proses austempering dengan 3 pemilihan suhu $350^{\circ} \mathrm{C}, 450^{\circ} \mathrm{C}, 550^{\circ} \mathrm{C}$ dan ditahan selama 30 menit. Metode yang digunakan untuk menguji dari hasil austempering adalah pengujian tarik dengan menggunakan ASTM A370- 12a, pengujian kekerasan Vickers dan pengamatan struktur mikro menggunakan mikroskop digital. Pada hasil pengujian tarik baja S 45 C dan S 60 C didapatkan nilai peningkatan keuletan dan ketangguhan sebesar $17,1 \%$ pada baja S 45 C dan 17\% pada baja S 60 C. Nilai ini didapatkan dari perhitungan ultimate tensile strength benda uji yang belum diproses austempering dengan benda uji yang sudah diproses austempering dengan suhu $350^{\circ} \mathrm{C}$, Dan pada hasil pengujian kekerasan baja S $45 \mathrm{C}$ dan $\mathrm{S}$ 60 C didapatkan nilai peningkatan kekerasan sebesar 44\% pada baja S 45 C dan 46\% pada baja S 60 C. Nilai ini didapatkan dari perhitungan nilai rata-rata benda uji yang belum diproses austempering dengan benda uji yang sudah diproses austempering dengan suhu $350^{\circ} \mathrm{C}$.
\end{abstract}

Kata Kunci: perlakuan panas, baja karbon, austempering, austemper, austemper baja karbon

\section{PENDAHULUAN}

Baja adalah besi karbon campuran logam yang berisi konsentrasi dari campuran logam lainnya yang mempunyai perlakuan bahan dan komposisi berbeda. Sebagian dari baja umumnya digolongkan menurut konsentrasi karbon, yakni ke dalam rendah, menengah, dan jenis karbon tinggi. Baja banyak digunakan karena baja mempunyai sifat mekanis lebih baik dari pada besi, sifat baja antara lain [3]:

1. Tangguh dan ulet;

2. Mudah ditempa;

3. Mudah diproses; 
4. Sifatnya dapat diubah dengan mengubah karbon;

5. Sifatnya dapat diubah dengan perlakuan panas;

6. Kadar karbon lebih rendah di banding besi;

7. Banyak dipakai untuk berbagai bahan peralatan.

Walaupun baja lebih sering digunakan, namun baja mempunyai kelemahan, yaitu ketahanan terhadap korosinya rendah. Baja dapat (dua unsur atau lebih digabung sehingga dihasilkan sifat lain) menghasilkan pemaduan, yaitu larutan padat/solid solufion (dapat memperbaiki sifat fisika/ kimia) dan senyawa (lebih keras dari larutan padat, dapat memperbaiki sifat mekanik).

Austemper termasuk salah satu cara perlakuan panas yang bertujuan meningkatkan ketangguhan (toughness) material. Komponen yang mengalami proses ini akan memiliki ketangguhan yang lebih tinggi, kekuatan impaknya menjadi lebih baik, kekuatan tarik dan kekerasan juga meningkat. Dalam melakukan proses austemper, dapat dilakukan dalam beberapa tahap, yaitu: (1) Tahap pemanasan; (2) Penahanan suhu austenisasi selama waktu tahan tertentu; (3) Tahap pendinginan; (4) Penahan suhu austemper; dan (5) Pendinginan dalam media udara.

\section{METODE PENELITIAN}

Metode penelitian dibuat untuk menyusun langkah-langkah yang akan dilakukan dalam melakukan penelitian sehingga penelitian berjalan secara sistematis dan terarah. Adapun langkahlangkah yang dilakukan dapat dilihat dalam Gambar 1 di bawah ini. Setelah pengujian dilakukan, data-data yang didapat akan dianalisa lebih lanjut. Tahap terakhir adalah kesimpulan dan saran.

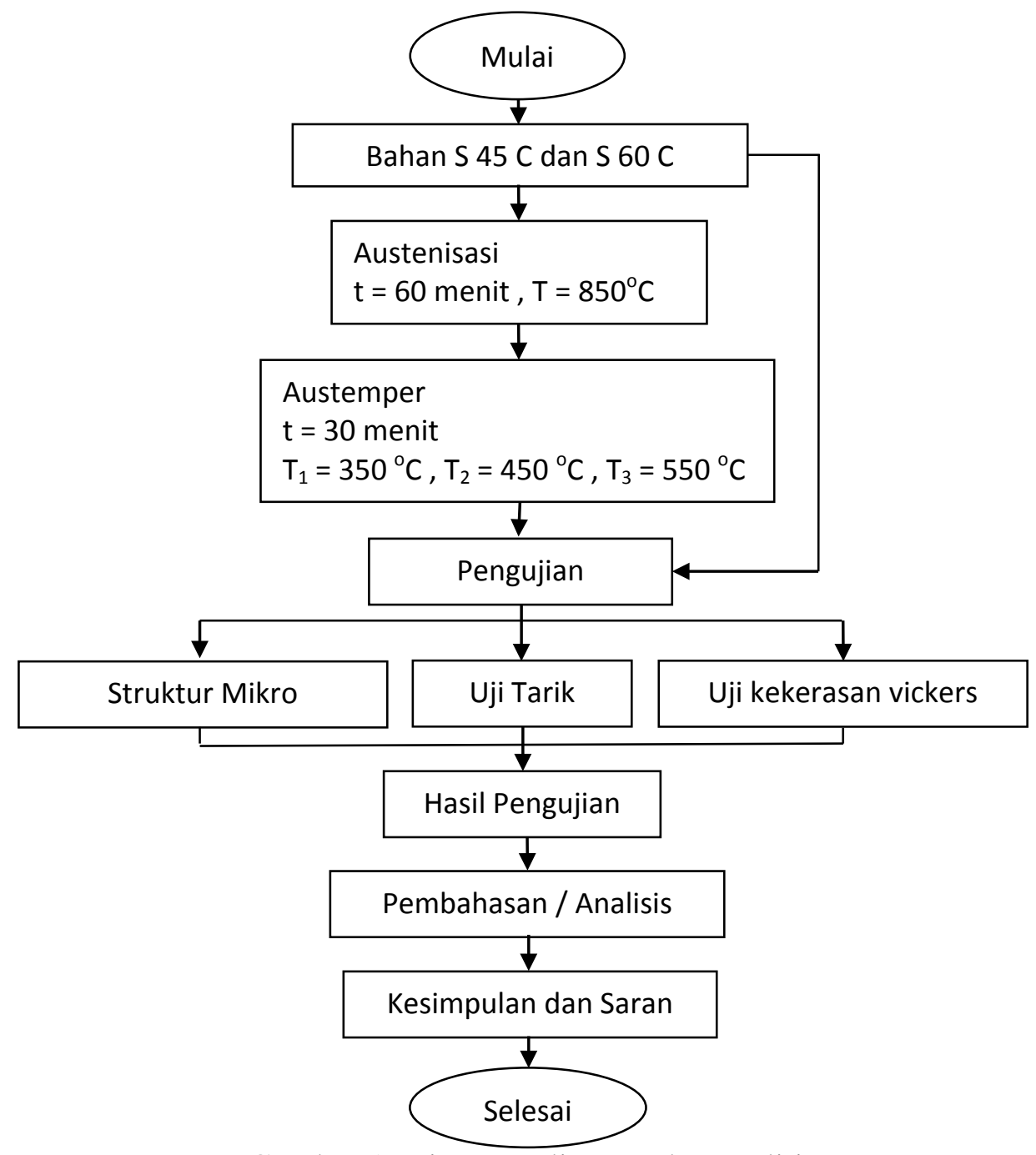

Gambar 1. Diagram alir metode penelitian 
Prosedur penelitian meliputi beberapa tahap, yaitu:

\section{a. Pemotongan baja}

Benda uji yang sudah dibentuk sesuai ASTM A370-12a dan sudah diproses austempering dilakukan pengujian tarik guna untuk mengetahui keuletan dan ketangguhan suatu bahan terhadap tegangan tertentu serta pertambahan panjang yang dialami oleh bahan tersebut.

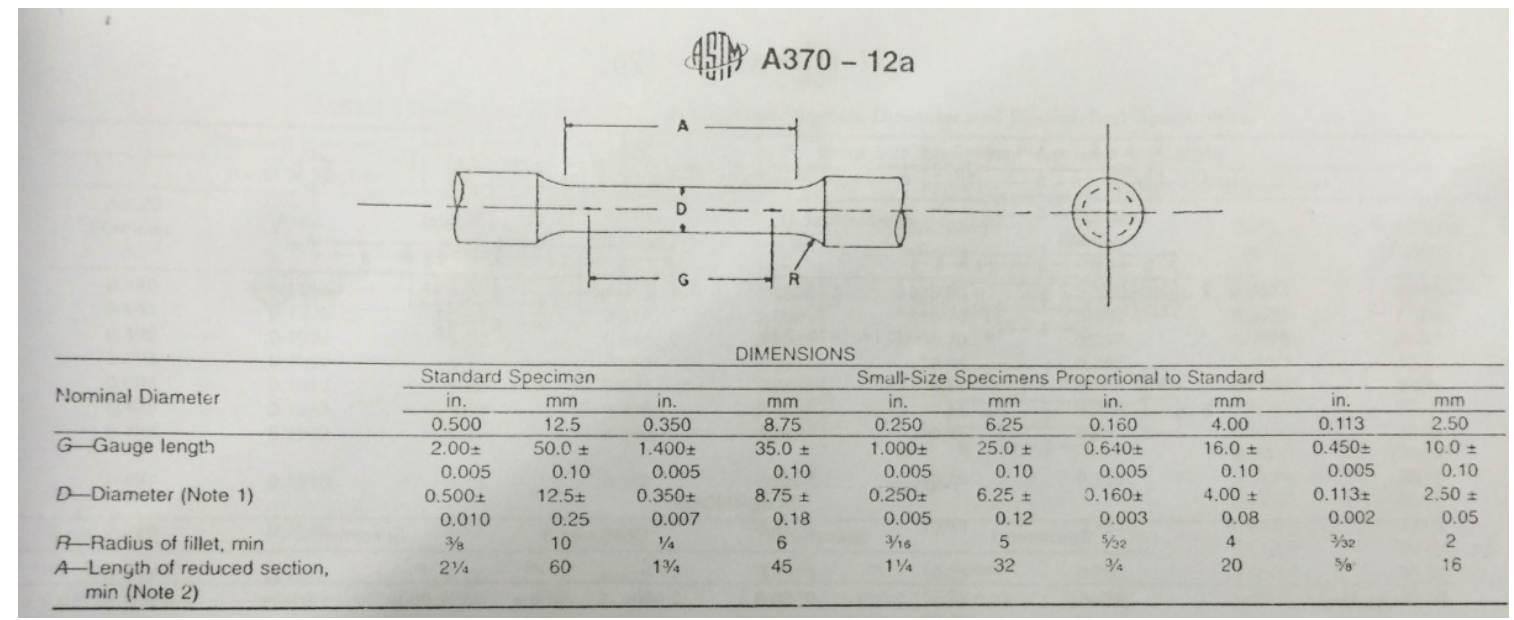

Gambar 2. ASTM A370-12a

\section{b. Pembuatan spesimen}

Pembuatan spesimen dengan melakukan mesin bubut agar bentuk yang diinginkan sesuai dengan ukuran dan bentuk ASTM.

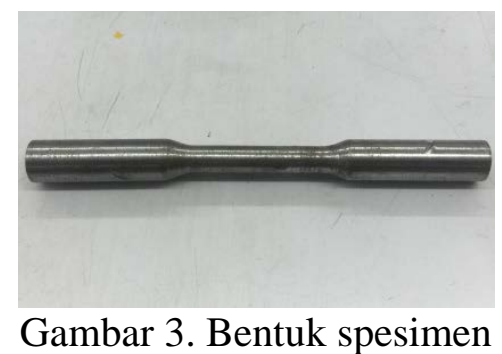

\section{HASIL DAN PEMBAHASAN}

a. Pembahasan Hasil Uji Tarik

Dari uji tarik yang telah dilakukan maka diperoleh hasil sebagai berikut :

Tabel 1. Hasil uji tarik pada Baja S 45 C

\begin{tabular}{cccccccccc}
\hline $\begin{array}{c}\text { Benda } \\
\text { uji }\end{array}$ & $\mathrm{d}(\mathrm{mm})$ & $\begin{array}{c}\mathrm{A} \\
\left(\mathrm{mm}^{2}\right)\end{array}$ & $\begin{array}{c}\mathrm{L}_{0} \\
(\mathrm{~mm})\end{array}$ & $\begin{array}{c}\mathrm{L} \\
(\mathrm{mm})\end{array}$ & $\begin{array}{c}\mathrm{Fy} \\
(\mathrm{Kgf})\end{array}$ & $\begin{array}{c}\mathrm{Fu} \\
(\mathrm{Kgf})\end{array}$ & $\begin{array}{c}\Sigma \mathrm{y} \\
\left(\mathrm{N} / \mathrm{mm}^{2}\right)\end{array}$ & $\begin{array}{c}\Sigma \mathrm{u} \\
\left(\mathrm{N} / \mathrm{mm}^{2}\right)\end{array}$ & $\mathrm{e} \mathrm{( \% )}$ \\
\hline Awal & 6,25 & 30,6 & 106 & 141 & 914 & 1576 & 293 & 505 & 33,1 \\
$350{ }^{0} \mathrm{C}$ & 6,25 & 30,6 & 106 & 136 & 1348 & 1807 & 432 & 579 & 28,3 \\
$450{ }^{\circ} \mathrm{C}$ & 6,25 & 30,6 & 106 & 139 & 1270 & 1754 & 407 & 562 & 31,1 \\
$550{ }^{\circ} \mathrm{C}$ & 6,25 & 30,6 & 106 & 147 & 1092 & 1601 & 350 & 513 & 38,6 \\
\hline
\end{tabular}

Keterangan :

d : diameter (mm)

A : luas benda uji $\left(\mathrm{mm}^{2}\right)$

$\mathrm{L} \quad$ : panjang benda uji awal (mm)

$\mathrm{L}_{0} \quad$ : panjang benda uji akhir $(\mathrm{mm})$

Fy : gaya yield (Kgf) 

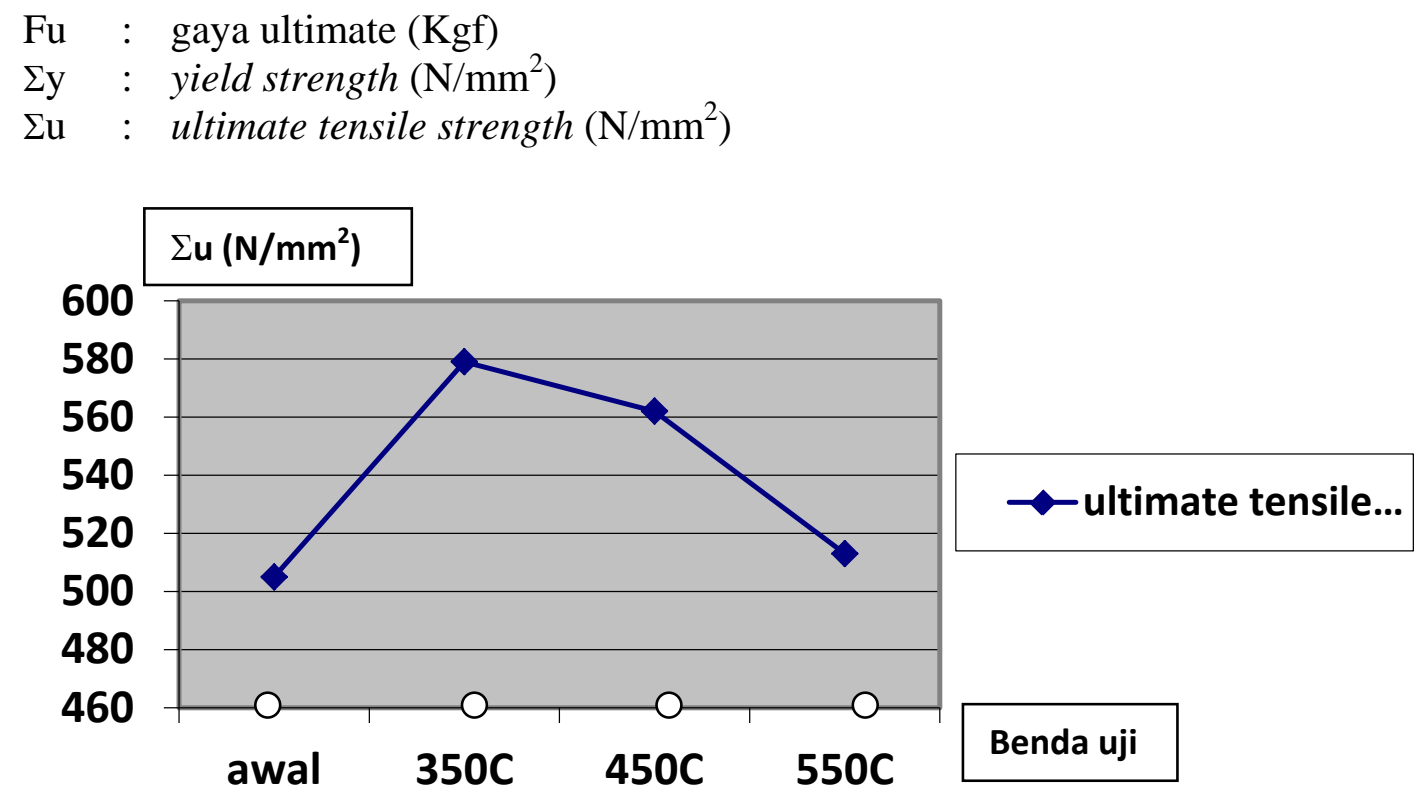

Gambar 4. Ultimate tensile strength S $45 \mathrm{C}$

Pada hasil pengujian tarik baja S 45 C didapatkan nilai peningkatan keuletan dan ketangguhan sebesar $14,6 \%$. Nilai ini didapatkan dari perhitungan ultimate tensile strength benda uji yang belum diproses austempering dengan benda uji yang sudah diproses austempering dengan suhu $350{ }^{\circ} \mathrm{C}$.

Tabel 2. Hasil uji tarik pada Baja S 60 C

\begin{tabular}{cccccccccc}
\hline $\begin{array}{c}\text { Benda } \\
\text { uji }\end{array}$ & $\mathrm{d}(\mathrm{mm})$ & $\begin{array}{c}\mathrm{A} \\
\left(\mathrm{mm}^{2}\right)\end{array}$ & $\begin{array}{c}\mathrm{L}_{0} \\
(\mathrm{~mm})\end{array}$ & $\begin{array}{c}\mathrm{L} \\
(\mathrm{mm})\end{array}$ & $\begin{array}{c}\mathrm{Fy} \\
(\mathrm{Kgf})\end{array}$ & $\begin{array}{c}\mathrm{Fu} \\
(\mathrm{Kgf})\end{array}$ & $\begin{array}{c}\Sigma \mathrm{y} \\
\left(\mathrm{N} / \mathrm{mm}^{2}\right)\end{array}$ & $\begin{array}{c}\Sigma \mathrm{u} \\
\left(\mathrm{N} / \mathrm{mm}^{2}\right)\end{array}$ & $\mathrm{e} \mathrm{( \% )}$ \\
\hline Awal & 6,25 & 30,6 & 106 & 132 & 968 & 1654 & 310 & 530 & 24,5 \\
$350{ }^{\circ} \mathrm{C}$ & 6,25 & 30,6 & 106 & 127 & 1461 & 1960 & 465 & 628 & 19,8 \\
$450{ }^{\circ} \mathrm{C}$ & 6,25 & 30,6 & 106 & 129 & 1298 & 1832 & 416 & 587 & 21,6 \\
$550{ }^{\circ} \mathrm{C}$ & 6,25 & 30,6 & 106 & 131 & 1120 & 1654 & 359 & 530 & 23,5 \\
\hline
\end{tabular}

Keterangan:

$\mathrm{d}=$ diameter $(\mathrm{mm})$

$\mathrm{A}=$ luas benda uji $\left(\mathrm{mm}^{2}\right)$

$\mathrm{L}=$ panjang benda uji awal (mm)

$\mathrm{L}_{0}=$ panjang benda uji akhir (mm)

$\mathrm{Fy}=$ gaya yield $(\mathrm{Kgf})$

$\mathrm{Fu}=$ gaya ultimate $(\mathrm{Kgf})$

$\Sigma \mathrm{y}=$ yield strength $\left(\mathrm{N} / \mathrm{mm}^{2}\right)$

$\Sigma \mathrm{u}=$ ultimate tensile strength $\left(\mathrm{N} / \mathrm{mm}^{2}\right)$

Pada hasil pengujian tarik baja S $60 \mathrm{C}$ didapatkan nilai peningkatan keuletan dan ketangguhan sebesar 18,4\%. Nilai ini didapatkan dari perhitungan ultimate tensile strength benda uji yang belum diproses austempering dengan benda uji yang sudah diproses austempering dengan suhu $350{ }^{0} \mathrm{C}$.

\section{b. Hasil uji kekerasan}

Uji kekerasan ini dilakukan dengan menggunakan Micro Hardness Tester. Adapun hasilhasil dari pengujian seperti ditunjukan pada Tabel 3, Tabel 4 dan Tabel 5. 


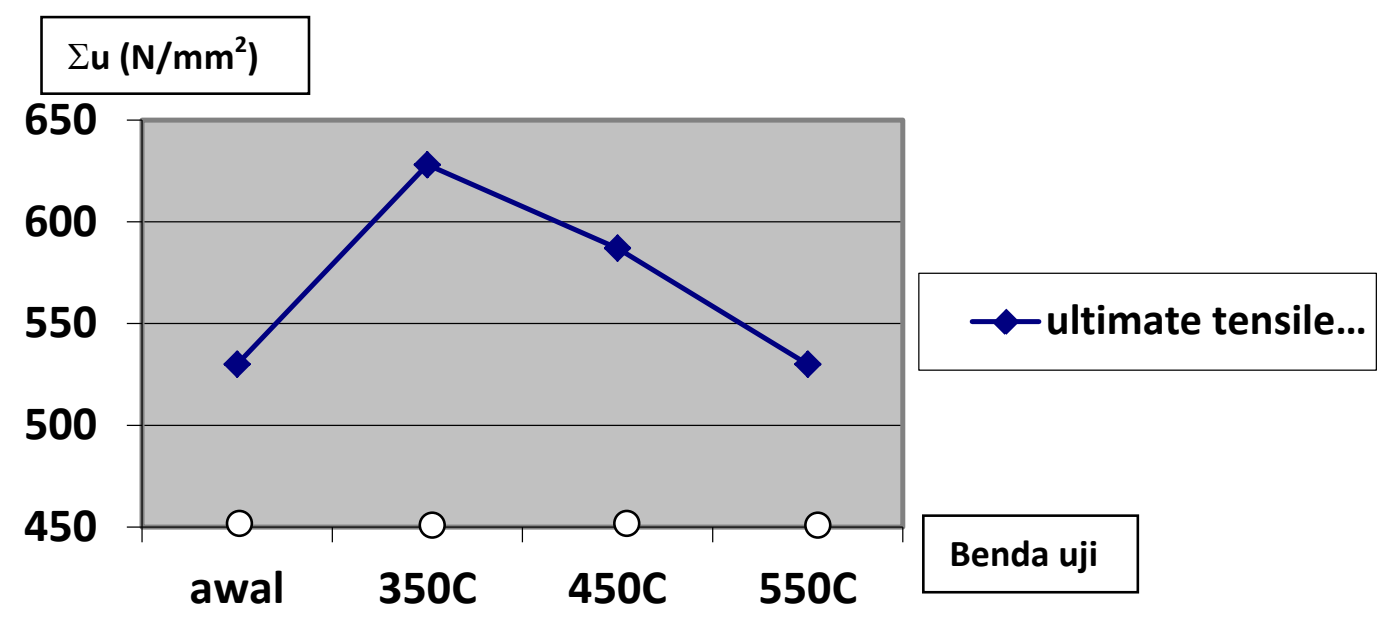

Gambar 5. Ultimate tensile strength S $60 \mathrm{C}$

Sebelum Proses

Tabel 3. Nilai kekerasan awal Baja S 45 C

\begin{tabular}{cc}
\hline Titik Uji & Kekerasan (HV) \\
\hline t1 & 232 \\
t2 & 226 \\
t3 & 221 \\
\hline Rata-rata & 226 \\
\hline
\end{tabular}

Tabel 4. Nilai kekerasan awal Baja S 60 C

\begin{tabular}{cc}
\hline Titik Uji & Kekerasan (HV) \\
\hline t1 & 235 \\
t2 & 232 \\
t3 & 236 \\
\hline Rata-rata & 234 \\
\hline
\end{tabular}

Setelah proses austempering

Tabel 5. Nilai kekerasan (HV) setelah austempering pada Baja S 45 C

\begin{tabular}{ccccc}
\hline $\begin{array}{c}\text { Suhu } \\
\text { Austemper }\end{array}$ & t1 & t2 & t3 & Rata-rata \\
\hline $350{ }^{0} \mathrm{C}$ & 418 & 419 & 421 & 419 \\
$450{ }^{\circ} \mathrm{C}$ & 315 & 313 & 316 & 315 \\
$550{ }^{\circ} \mathrm{C}$ & 278 & 286 & 280 & 281 \\
\hline
\end{tabular}

Disini terlihat kekerasan benda uji pada baja S $45 \mathrm{C}$ mengalami peningkatan untuk tiap-tiap suhu austempernya. Kekerasan tertinggi pada suhu austemper $350{ }^{\circ} \mathrm{C}$, lalu $450^{\circ} \mathrm{C}$ dan $550^{\circ} \mathrm{C}$.

Pada hasil pengujian kekerasan baja S 45 C didapatkan nilai peningkatan kekerasan sebesar 44\%. Nilai ini didapatkan dari perhitungan nilai rata-rata benda uji yang belum diproses austempering dengan benda uji yang sudah diproses austempering dengan suhu $350^{\circ} \mathrm{C}$. 


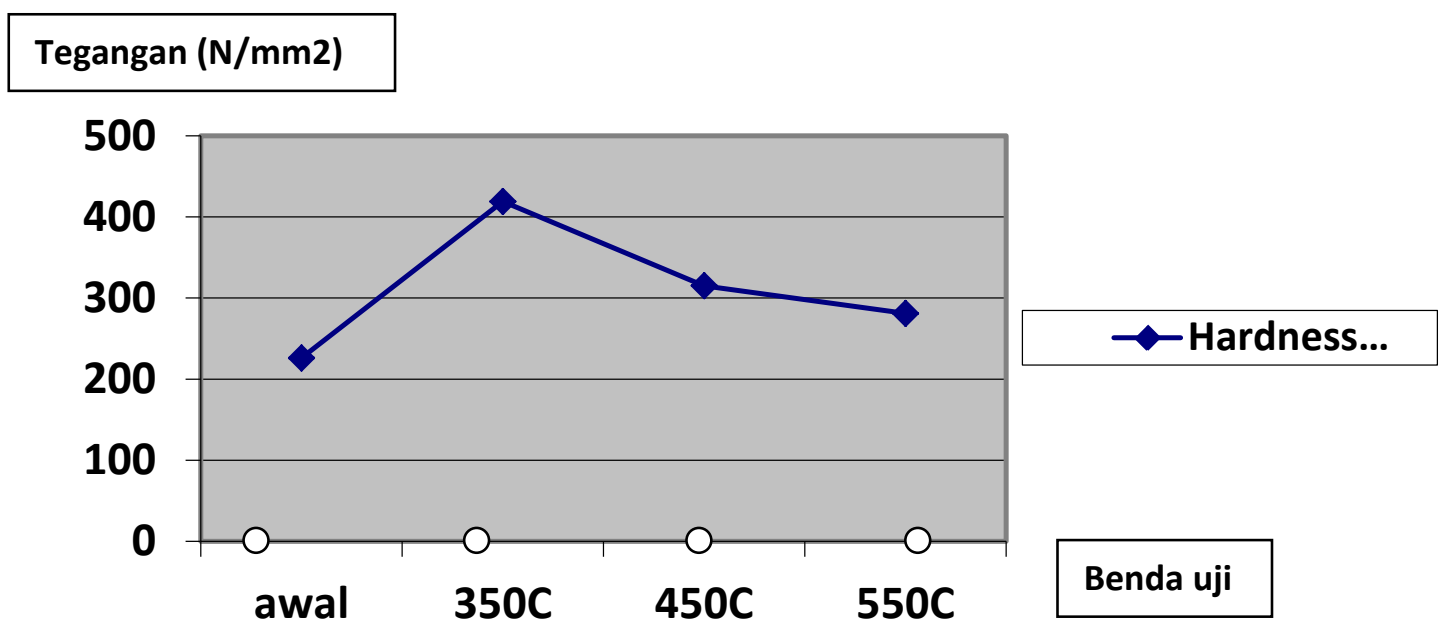

Gambar 6. Grafik tegangan S 45 C

Tabel 6. Nilai kekerasan (HV) setelah austempering pada Baja S 60 C

\begin{tabular}{ccccc}
\hline $\begin{array}{c}\text { Suhu } \\
\text { Austemper }\end{array}$ & t1 & t2 & t3 & Rata-rata \\
\hline $350{ }^{\circ} \mathrm{C}$ & 441 & 433 & 430 & 434 \\
$450{ }^{\circ} \mathrm{C}$ & 312 & 331 & 335 & 326 \\
$550{ }^{\circ} \mathrm{C}$ & 282 & 282 & 286 & 283 \\
\hline
\end{tabular}

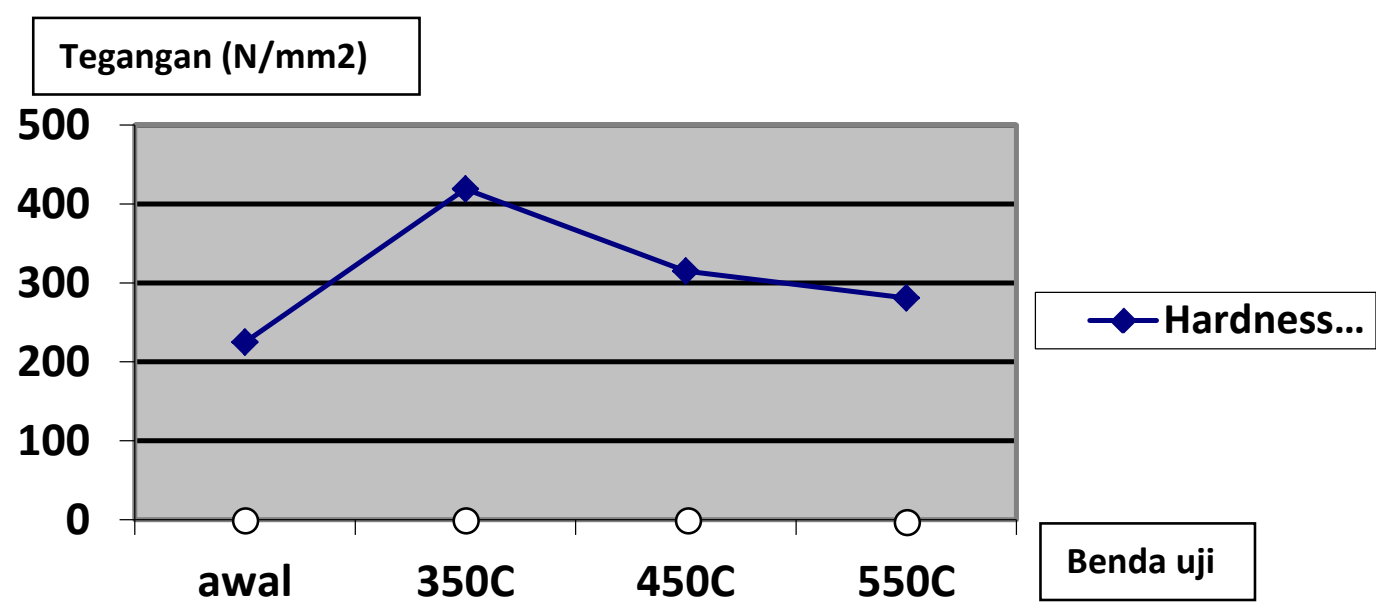

Gambar 7. Grafik tegangan S 60 C

Setelah benda uji mengalami proses austemper, disini terlihat bahwa ada peningkatan nilai kekerasan dibandingkan dengan sebelum proses. Kekerasan paling tinggi dihasilkan oleh proses austemper dengan suhu $350^{\circ} \mathrm{C}$, lalu diikuti dengan $450^{\circ} \mathrm{C}$ dan $550^{\circ} \mathrm{C}$.

Setelah kita melihat dan menganalisa tiap-tiap proses austemper tersebut, maka dapat kita lihat dengan jelas bahwa nilai kekerasan benda uji semakin menurun nilainya seiring dengan semakin tingginya suhu austemper yang dilakukan. Hal itu di karenakan semakin tinggi suhu austempernya maka semakin lama juga pendingin yang terjadi. Apabila pendinginan tidak cepat makan fasa bainit semakin dikit, karena fasa bainit terbentuk pada saat pendinginan secara cepat.

Pada hasil pengujian kekerasan baja S 60 C didapatkan nilai peningkatan kekerasan sebesar 46\%. Nilai ini didapatkan dari perhitungan nilai rata-rata benda uji yang belum diproses austempering dengan benda uji yang sudah diproses austempering dengan suhu $350{ }^{\circ} \mathrm{C}$. 


\section{c. Pengamatan struktur mikro}

Pengamatan ini dilakukan dengan menggunakan mikroskop digital yang dilengkapi dengan komputer untuk mengamati struktur mikro dari benda uji. Dibantu dengan $\mathrm{HNo}_{3} 3 \%+$ Alkohol 97\%. Adapun hasil pengujian tersebut adalah sebagai berikut:

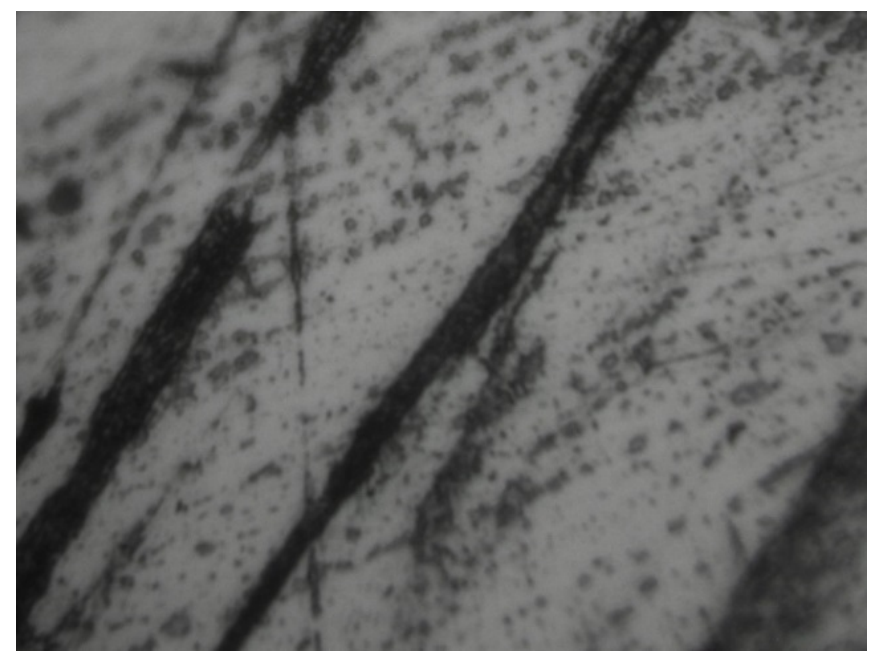

Gambar 8. Struktur mikro benda uji mula-mula Baja S 45 C.

Pembesaran foto 500x

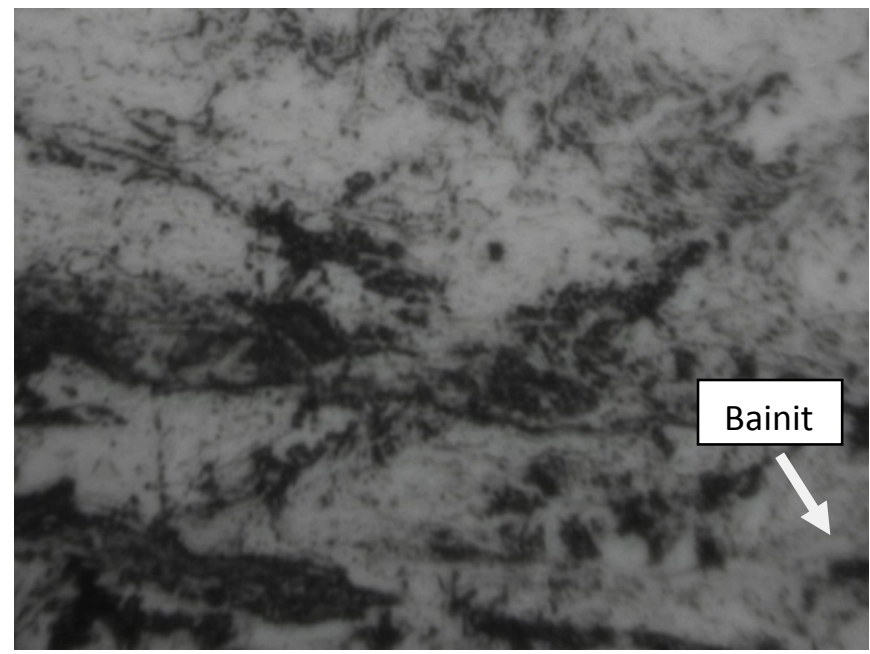

Gambar 9. Struktur mikro benda uji Baja S 45 C pada proses austempering $350{ }^{\circ} \mathrm{C}$.

Pembesaran Foto 500x

Pada Gambar 9 terlihat bahwa struktur mikro benda uji baja S 45 C pada proses austempering $350^{\circ} \mathrm{C}$ terlihat bahwa fasa bainit paling mendominan. Fasa bainit ini lah yang menyebabkan proses austempering $350^{\circ} \mathrm{C}$ menjadi proses yang paling kuat pada saat pengujian tarik dan pengujian kekerasan.

Pada Gambar 10 terlihat bahwa struktur mikro benda uji baja S 45 C pada proses austempering $450{ }^{\circ} \mathrm{C}$ terlihat bahwa terdapat fasa bainit dan austenit. Walaupun Fasa bainit masih mendominan. ini lah yang menyebabkan proses austempering $450{ }^{0} \mathrm{C}$ menjadi proses yang lebih kuat pada saat pengujian tarik dan pengujian kekerasan dibandingkan dengan proses austempering $550^{\circ} \mathrm{C}$.

Pada Gambar 11 terlihat bahwa struktur mikro benda uji baja S 45 C pada proses austempering $550{ }^{\circ} \mathrm{C}$ terlihat bahwa terdapat fasa bainit dan austenite yang lebih dominan. ini lah yang menyebabkan proses austempering $550{ }^{0} \mathrm{C}$ menjadi proses yang kurang kuat pada saat 
pengujian tarik dan pengujian kekerasan dibandingkan dengan proses austempering $350{ }^{0} \mathrm{C}$ dan $450^{\circ} \mathrm{C}$.

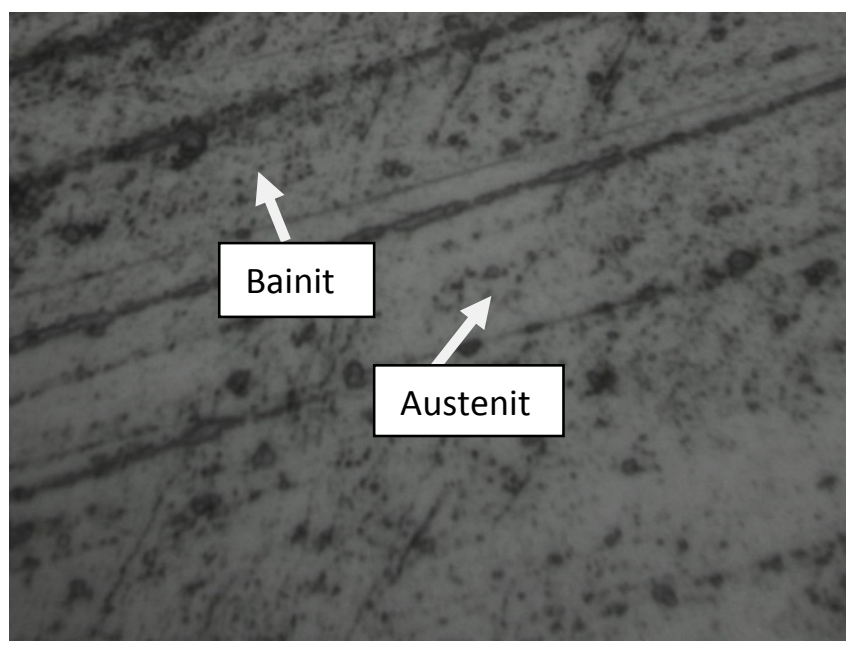

Gambar 10. Struktur mikro benda uji Baja S 45 C pada proses austempering $450^{\circ} \mathrm{C}$. Pembesaran foto 500x

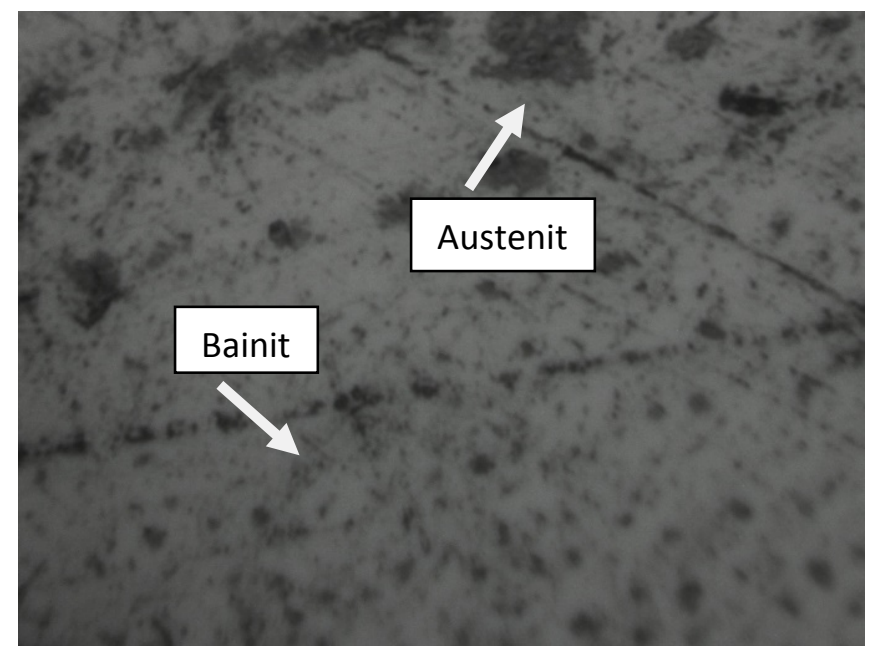

Gambar 11. Struktur mikro benda uji Baja S 45 C pada proses austempering $550{ }^{\circ} \mathrm{C}$. Pembesaran foto 500x

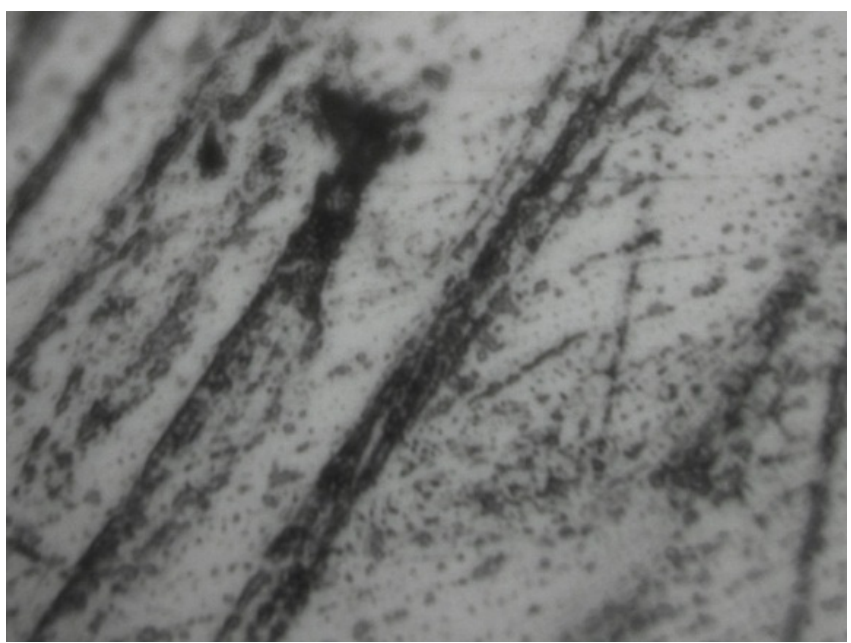

Gambar 12. Struktur Mikro Benda Uji Mula-mula Baja S 60 C. Pembesaran foto 500x 


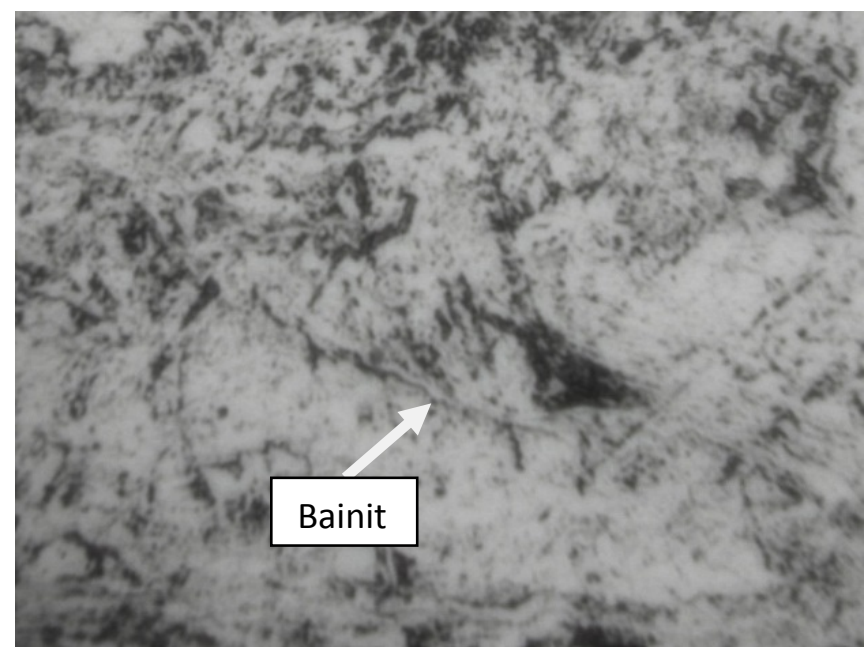

Gambar 13. Struktur mikro benda uji Baja S $60 \mathrm{C}$ pada proses austempering $350{ }^{\circ} \mathrm{C}$.

Pembesaran foto 500x

Pada Gambar 13 terlihat bahwa struktur mikro benda uji baja S 60 C pada proses austempering $350{ }^{0} \mathrm{C}$ terlihat bahwa fasa bainit paling mendominan. Fasa bainit ini lah yang menyebabkan proses austempering $350{ }^{0} \mathrm{C}$ menjadi proses yang paling kuat pada saat pengujian tarik dan pengujian kekerasan.

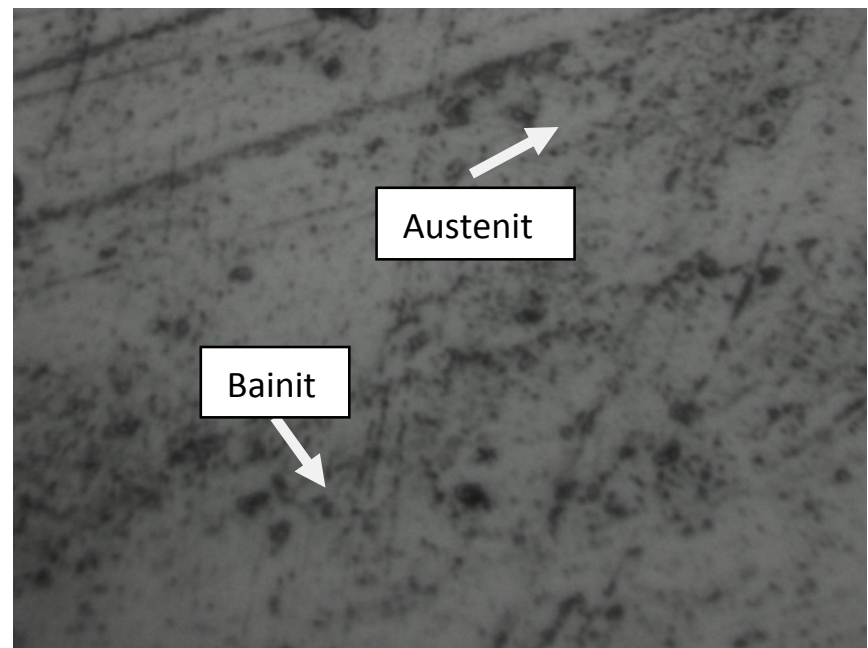

Gambar 14. Struktur mikro benda uji baja S 60 C pada proses austempering $450{ }^{\circ} \mathrm{C}$.

Pembesaran foto 500x.

Pada Gambar 14 terlihat bahwa struktur mikro benda uji baja S 60 C pada proses austempering $450{ }^{\circ} \mathrm{C}$ terlihat bahwa terdapat fasa bainit dan austenit. Walaupun Fasa bainit masih mendominan. ini lah yang menyebabkan proses austempering $450^{\circ} \mathrm{C}$ menjadi proses yang lebih kuat pada saat pengujian tarik dan pengujian kekerasan dibandingkan dengan proses austempering $550^{\circ} \mathrm{C}$.

Pada Gambar 15 terlihat bahwa struktur mikro benda uji baja S 60 C pada proses austempering $550{ }^{0} \mathrm{C}$ terlihat bahwa terdapat fasa bainit dan austenite yang lebih dominan. inilah yang menyebabkan proses austempering $550^{\circ} \mathrm{C}$ menjadi proses yang kurang kuat pada saat pengujian tarik dan pengujian kekerasan dibandingkan dengan proses austempering $350{ }^{0} \mathrm{C}$ dan $450^{\circ} \mathrm{C}$.

Dari hasil cetak, dapat terlihat dengan jelas perbedaan fasa bainit yang terbentuk pada temperatur asutempering yang berbeda. Pada temperatur $350^{\circ} \mathrm{C}$ paling banyak terdapat fasa bainit. Semakin tinggi temperature austempering maka semakin sedikit fasa bainit nya. 


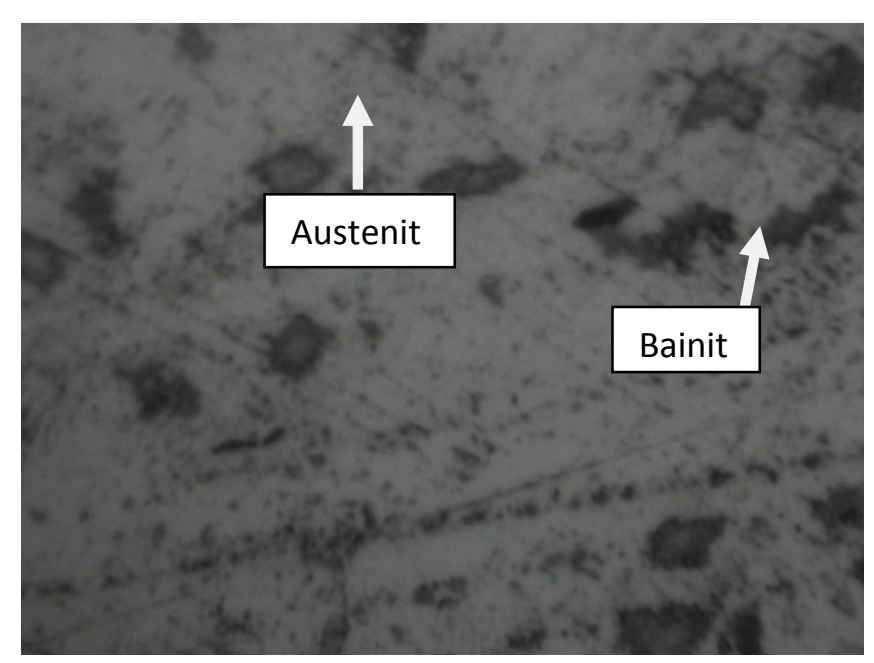

Gambar 15. Struktur mikro benda uji baja S $60 \mathrm{C}$ pada proses austempering $550^{\circ} \mathrm{C}$. Pembesaran foto 500x

\section{KESIMPULAN}

Berdasarkan penelitian pengaruh proses austemper pada kekuatan mekanis dan struktur mikro dari baja S45C dan S60C, maka dapat diambil kesimpulan sebagai berikut :

1. Temperatur austemper sangat berpengaruh dalam memperoleh hasil nilai kekerasan yang diinginkan. Semakin tinggi temperature austemper, maka semakin rendah nilai kekerasan yang diperoleh pada baja S 45 C dan S 60 C. Nilai kekerasan tertinggi didapat pada temperatur $350^{\circ} \mathrm{C}$, sedangkan nilai terendah didapat pada suhu $550^{\circ} \mathrm{C}$.

2. Temperatur austemper sangat berpengaruh dalam memperoleh hasil nilai kekuatan tarik yang diinginkan. Semakin tinggi temperature austemper, maka semakin rendah nilai kekuatan tarik yang diperoleh pada baja S 45 C dan S 60 C. Nilai kekuatan tarik tertinggi didapat pada temperature $350^{\circ} \mathrm{C}$, sedangkan nilai terendah didapat pada suhu $550^{\circ} \mathrm{C}$.

3. Struktur mikro bainit terbanyak pada baja S $45 \mathrm{C}$ dan S $60 \mathrm{C}$ di dapatkan pada proses austemper dengan suhu $350^{\circ} \mathrm{C}$.

4. Pada hasil pengujian tarik baja S $45 \mathrm{C}$ dan S $60 \mathrm{C}$ didapatkan nilai peningkatan keuletan dan ketangguhan sebesar 14,6\% pada baja S 45 C dan 18,4\% pada baja S 60 C. Nilai ini didapatkan dari perhitungan ultimate tensile strength benda uji yang belum diproses austempering dengan benda uji yang sudah diproses austempering dengan suhu $350^{\circ} \mathrm{C}$.

5. Pada hasil pengujian kekerasan baja S 45 C dan S 60 C didapatkan nilai peningkatan kekerasan sebesar $44 \%$ pada baja S 45 C dan $46 \%$ pada baja S 60 C. Nilai ini didapatkan dari perhitungan nilai rata-rata benda uji yang belum diproses austempering dengan benda uji yang sudah diproses austempering dengan suhu $350^{\circ} \mathrm{C}$.

\section{DAFTAR PUSTAKA}

[1]. Devinta Jualiaptini, Analisis Sifat Mekanik dan Metalografi Baja Karbon Rendah Untuk Aplikasi Tabung Gas 3KG, Universitas Islam Negeri Syarif Hidayatullah, Tangerang, 2010.

[2]. Dwi Indarto, Pengaruh Waktu Tahan Proses Hot Dipping Baja Karbon Rendah Terhadap Ketebalan Lapisan, Kekuatan Tarik dan Harga Impak Dengan Bahan Pelapis Alumunium, Universitas Muhammadiyah, Surakarta, 2009.

[3]. Eddy Susanto, Pengaruh Proses Austempering Terhadap Kekuatan Mekanis dan Struktur Mikro dari Baja Karbon Sedang, Universitas Tarumanagara, Jakarta, 1998.

[4]. Joko Waluyo, Pengaruh Temperatur dan Waktu Tahan Pada Proses Karburisasi Cair Terhadap Kekerasan Baja AISI 1025 dengan Media Pendinginan Air, Universitas Sebelas Maret, Surakarta, 2009. 
[5]. Serope Kalpakjian, Steven Schmid. Manufacturing Processes for Engineering Materials, Pearson Education, Singapore, 2003.

[6]. Harry, Chandler. Hardness testing, $2^{\text {nd }}$ Edition, ASM Internasional, 1999

[7]. George E. Totten, Ph. D., FASM. Steel Heat Treatment Metallurgy and Technologies, second edition, Portland State University. Portland, Oregeon, USA, 2007.

[8]. Tata Surdia, Shinroku Saito. Pengetahuan Bahan Teknik, PT Pradnya Paramita Jakarta, 1985.

[9]. William H. Cubberly. ASM Handbook Metalography anda Microstructures Volume 9, Formely Minth Edition, Metals Handbook. 1985.

[10]. Suratman, Rochim. Panduan Proses Perlakuan Panas. Lembaga Penelitian ITB. Bandung, 1994.

[11]. William, F. Smith. Structure and Properties of engineering Alloys, Me Graw - Hill Book Company, New York, 1981. 